Atmos. Meas. Tech., 10, 2353-2359, 2017

https://doi.org/10.5194/amt-10-2353-2017

(C) Author(s) 2017. This work is distributed under

the Creative Commons Attribution 3.0 License.

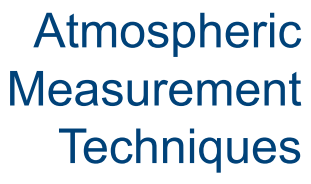

(c) (P)

\title{
Brown carbon absorption in the red and near-infrared spectral region
}

\author{
András Hoffer ${ }^{1}$, Ádám Tóth ${ }^{2}$, Mihály Pósfai ${ }^{2}$, Chul Eddy Chung ${ }^{3}$, and András Gelencsér ${ }^{1,2}$ \\ ${ }^{1}$ MTA-PE Air Chemistry Research Group, Veszprém, P.O. Box 158, 8201, Hungary \\ ${ }^{2}$ Department of Earth and Environmental Sciences, University of Pannonia, Veszprém, P.O. Box 158, 8201, Hungary \\ ${ }^{3}$ Division of Atmospheric Sciences, Desert Research Institute, Reno, NV 89512, USA
}

Correspondence to: András Gelencsér (gelencs@almos.uni-pannon.hu)

Received: 29 November 2016 - Discussion started: 12 January 2017

Revised: 15 May 2017 - Accepted: 16 May 2017 - Published: 28 June 2017

\begin{abstract}
Black carbon (BC) aerosols have often been assumed to be the only light-absorbing carbonaceous particles in the red and near-infrared spectral regions of solar radiation in the atmosphere. Here we report that tar balls (a specific type of organic aerosol particles from biomass burning) do absorb red and near-infrared radiation significantly. Tar balls were produced in a laboratory experiment, and their chemical and optical properties were measured. The absorption of these particles in the range between 470 and $950 \mathrm{~nm}$ was measured with an aethalometer, which is widely used to measure atmospheric aerosol absorption. We find that the absorption coefficient of tar balls at $880 \mathrm{~nm}$ is more than $10 \%$ of that at $470 \mathrm{~nm}$. The considerable absorption of red and infrared light by tar balls also follows from their relatively low absorption Ångström coefficient (and significant mass absorption coefficient) in the spectral range between 470 and $950 \mathrm{~nm}$. Our results support the previous finding that tar balls may play an important role in global warming. Due to the non-negligible absorption of tar balls in the near-infrared region, the absorption measured in the field at near-infrared wavelengths cannot solely be due to soot particles.
\end{abstract}

\section{Introduction}

In atmospheric science, black carbon (BC), a.k.a soot, aerosols have often been assumed to be the only lightabsorbing carbonaceous particles in the red and near-infrared spectral regions of solar radiation in the atmosphere. Organic aerosols (OAs) are currently treated as either being weak absorbers of sunlight in the UV/blue region or having no so- lar absorption in most radiation models (Myhre et al., 2013). Light-absorbing organic aerosols are also known as brown carbon $(\mathrm{BrC})$ since they absorb blue light significantly but have practically zero absorption in the red band, yielding brownish colours (Andreae and Gelencsér, 2006). The distinction between the light absorption by $\mathrm{BC}$ and $\mathrm{BrC}$ in field and laboratory studies has relied on the explicit assumption that no carbonaceous particle type except BC absorbs solar radiation at a wavelength of $\sim 700 \mathrm{~nm}$ or larger (Bahadur et al., 2012; Kirchstetter and Thatcher, 2012; Lu et al., 2015; Drinovec et al., 2017). This common assumption has been used in spite of the finding by Alexander et al. (2008), who showed a sizable absorption by a specific class of $\mathrm{BrC}$ at longer wavelengths. Alexander et al. (2008) named these $\mathrm{BrC}$ particles "brown carbon spheres", indicating that the morphology of these particles is similar to that of tar balls. Alexander et al. (2008) derived the absorption using highspatial-resolution electron energy-loss spectroscopy (EELS), which is not a direct method for absorption measurements. Not long ago Saleh et al. (2014) identified extremely low volatility compounds (ELVOCs) in biomass burning aerosols and calculated the index of refraction of these compounds. They found that these compounds absorb light in the nearinfrared range as well, and as $\mathrm{BrC}$ components they have an important role in direct radiative forcing.

The sources of atmospheric $\mathrm{BrC}$ are manifold, ranging from biomass burning emissions to secondary formation in photochemical reactions yielding absorbing particles of various absorption efficiencies (Limbeck et al., 2003; Lukács et al., 2007). The optical properties as well as particle morphologies and mixing state of $\mathrm{BrC}$ from different combus- 
tion sources are highly variable. The chemical composition and consequently the absorption properties of the $\mathrm{BrC}$ components depend on the formation processes (Laskin et al., 2015). The absorption Ångström exponent (AAE) of $\mathrm{BrC}$ varies between 2 and 11 , and the mass absorption coefficient of the water-insoluble fraction is generally much higher than that of the water-soluble fraction (Laskin et al., 2015). Smoldering combustion of peat yielded a variety of particles including spherical ones and agglomerates typically having a higher bulk oxygen-to-carbon ratio (Chakrabarty et al., 2016) than that reported by Pósfai et al. (2004). These compositional differences likely resulted in a significantly higher Ångström exponent for the various particles formed in slow-burning processes at low temperature than that for laboratory-generated "pure" tar balls with a $\mathrm{C} / \mathrm{O}$ ratio of about 10 and distinctive morphology (Hoffer et al., 2016). The C / O ratio and optical properties of the different duff smoke particles studied by Chakrabarty et al. (2010) resembled the properties of humic-like substances which are watersoluble and are on the less absorbing side of the $\mathrm{BrC}$ continuum.

Tar balls are widespread in biomass burning smoke (Pósfai et al., 2004; Adachi and Buseck, 2011). These particles clearly belong to the class of $\mathrm{BrC}$ and not to $\mathrm{BC}$, as they are distinctly different from $\mathrm{BC}$ in their morphology and other definition properties (Petzold et al., 2013). Tar balls are typically present as spherical solid particles with diameters in the range of $25-500 \mathrm{~nm}$ and can be readily identified by transmission electron microscopy-energy dispersive spectroscopy (TEM-EDS), as opposed to BC particles, which always have fractal-like morphology. Both tar ball and $\mathrm{BC}$ particles are refractory as they can withstand the high vacuum and the irradiation by the electron beam in the TEM indefinitely. As far as elemental composition is concerned, fresh tar balls are nearly homogeneous mixtures of carbon and oxygen at a molar ratio of about 10:1 as determined by TEM-EDS (Pósfai et al., 2004). While BC particles are primarily formed in fossil fuel combustion and in the flaming stages of biomass fires, tar balls are abundant in relatively aged smoke plumes from smoldering biomass fires (Pósfai et al., 2004).

Recently Tóth et al. (2014) have demonstrated that tar balls very similar to those observed in the atmosphere can be directly produced in the laboratory from liquid tar obtained by the dry distillation of wood chops. Based on these laboratory experiments the authors postulated that during biomass combustion tar ball particles are generated by the direct ejection of liquid tar droplets from the pores followed by a thermal shock in the fire zone and further atmospheric aging in biomass smoke plumes. This method allows us to directly measure the optical properties of tar balls without the interference of a multitude of other combustion particles. Hoffer et al. (2016) measured the optical properties of tar balls generated in the laboratory only up to wavelengths of $652 \mathrm{~nm}$; thus the absorption characteristics of tar balls in the infrared (IR) region were not discussed in that paper. In this study we used the very same method to generate tar ball particles in the laboratory as before, but the absorption characteristics of the tar balls were also measured directly with a single-spot seven-wavelength aethalometer (MAGEE AE42-7) at wavelengths of 880 and $950 \mathrm{~nm}$. This is the first direct experimental measurement of the IR absorption of "pure" BrC-type particles (tar balls) that are abundant in biomass burning plumes but are definitely not BC.

\section{Experimental procedure}

In this study tar balls were generated in an experimental setup similar to that used by Hoffer et al. (2016). Briefly, liquid tar was produced from dry distillation of two different wood types (Robinia pseudoacacia (black locust) and Picea abies (Norway spruce)) similar to the procedure described in Tóth et al. (2014). The obtained liquid distillate consisted of an aqueous phase and an oily phase. During the experiments, only the aqueous phase was used. This phase was concentrated and taken up with methanol. Droplets were then generated from the methanol solution by an ultrasonic atomizer (1.6 MHz, Exo Terra Fogger, PT2080, Rolf C. Hagen Corp), and they were aged by heat at $650{ }^{\circ} \mathrm{C}$ for about $1 \mathrm{~s}$, using a tube furnace (Carbolite, MTF 10/25/130). This ageing process is of utmost important as it influences the chemical composition and optical properties of the formed particles (Hoffer et al., 2016). During the particle generation the system was continually rinsed with $\mathrm{N}_{2}$ containing $4 \%(v / v) \mathrm{O}_{2}$. The particles were then dried and diluted with dry filtered air. Before the optical measurements a $\mathrm{PM}_{1}$ cyclone (SCC 2.229) was deployed to remove the large particles $\left(D_{p}>\sim 500 \mathrm{~nm}\right)$.

The absorption properties of the particles were measured with two optical instruments at different wavelengths. The absorption coefficient at 467, 528 and $652 \mathrm{~nm}$ was measured with a continuous light absorption photometer (CLAP) with a time resolution of $5 \mathrm{~s}$. In order to extend the measurements of the optical properties into the longer wavelength range (at 880 and $950 \mathrm{~nm}$ ), an aethalometer (MAGEE AE427) was applied with a time resolution of $2 \mathrm{~min}$. The CLAP data whose measurement principle is similar to that of the particle soot absorption photometer (PSAP) are corrected according to Bond et al. (1999) and Ogren (2010) with the data processing algorithm applied by NOAA. The aethalometer data were corrected according to the Weingartner correction scheme (Weingartner et al., 2003) and also by the Schmid correction (Schmid et al., 2006). The latter largely affects the Ångström exponent, whereas the former correction scheme has no effect on the Ångström exponent (Collaud Coen et al., 2010). In the correction we used the absorption coefficient measured by the CLAP at $528 \mathrm{~nm}$ as the reference value, keeping in mind that its reliability on the absolute scale is about $25 \%$ (Schmid et al., 2006).

The scattering coefficient was measured by a TSI 3563 nephelometer at three different wavelengths $(450,550$ and 


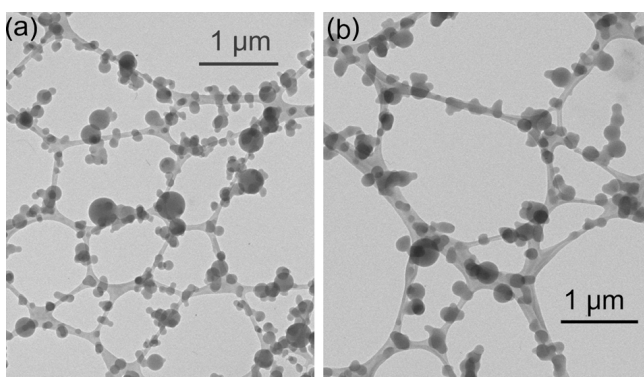

Figure 1. TEM images of tar balls generated from (a) black locust (Robinia pseudoacacia) and (b) Norway spruce (Picea abies).

$700 \mathrm{~nm}$ ) with a time resolution of $5 \mathrm{~s}$. The collected raw data were corrected according to Anderson and Ogren (1998).

During the experiment the size distribution between 7 and $800 \mathrm{~nm}$ was measured with a differential mobility particle sizer (DMPS) designed by the University of Helsinki.

The morphology and the elemental composition of the tar balls collected on TEM grids (lacey Formvar-carbon TEM copper grid of 200 mesh, Ted Pella Inc., USA) were studied in bright-field TEM images obtained using a Philips CM20 TEM operated at $200 \mathrm{kV}$ accelerating voltage. An ultra-thinwindow Bruker QUANTAX X-ray detector was attached to the electron microscope that allowed the energy-dispersive $\mathrm{X}$-ray analysis (EDS) of the elemental compositions of individual particles.

\section{Results}

\subsection{Morphology and size distribution of generated tar balls}

Figure 1 shows that the morphology of the generated particles is very similar to that of the freshly formed tar balls (Adachi and Buseck, 2011), as the particles are perfect or slightly distorted spheres. The size distribution measured with a DMPS was similar to that obtained previously by Hoffer et al. (2016). The volume size distribution consists of double peaks; the larger is at 116 and $139 \mathrm{~nm}$ in the case of black locust and Norway spruce, respectively (see Fig. 2). In this mode more than $96 \%$ of the particulate mass can be found. There is no difference in the molar $\mathrm{C} / \mathrm{O}$ ratio between tar balls generated from the two wood types; it varies between 8.1 and 11.6 with an average of 9.3 as determined from TEMEDS analyses.

\subsection{Absorption properties of the generated tar balls}

The AAEs of the tar balls generated from the aqueous phase of the dry distillate from black locust and Norway spruce measured by the CLAP between 467 and $652 \mathrm{~nm}$ are 2.9 and 3.2, respectively (see Fig. 3). Similar values are obtained from the aethalometer data between 470 and $590 \mathrm{~nm}$

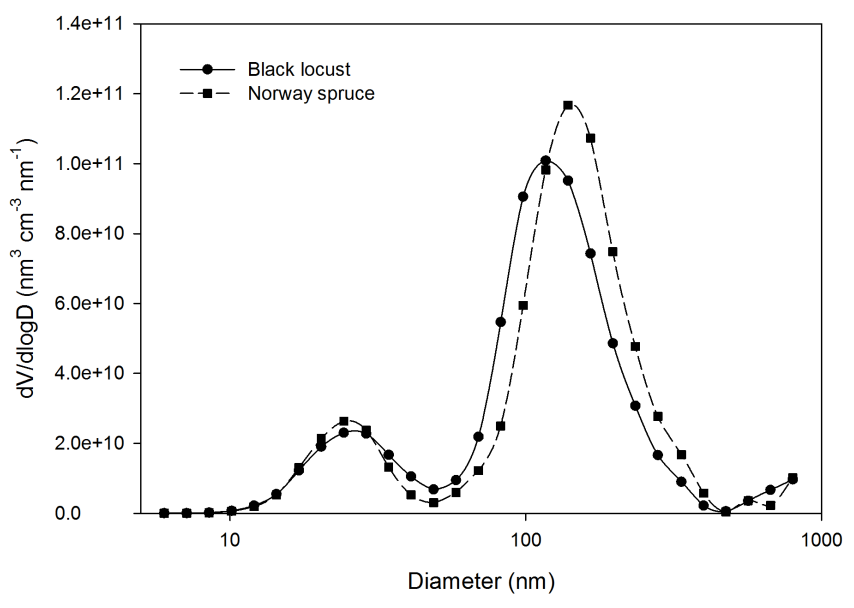

Figure 2. Examples of the measured size distribution of laboratorygenerated tar balls from the dry distillate of black locust and Norway spruce.

using the Weingartner correction scheme (Weingartner et al., 2003). The AAEs in the same wavelength range (470$590 \mathrm{~nm}$ ) for the black locust and Norway spruce calculated from the aethalometer data and corrected according to the Schmid correction scheme (Schmid et al., 2006) are 3.2 and 3.5 , respectively.

The absorption measured at $370 \mathrm{~nm}$ by the aethalometer was, however, significantly lower than would be predicted from AAE curve fitting. That is why the absorption data at this wavelength were omitted in the AAE calculations. Figure 3 shows that the AAE between 470 and 950 obtained by curve fitting is 3.1-3.2 and 3.4-3.6, depending on the applied correction scheme (Schmid correction gives higher values) for the black locust and Norway spruce, respectively. The error bars in Fig. 3 indicate the estimated $25 \%$ uncertainty of the absorption measurements for all wavelengths. This uncertainty value was reported for a one-wavelength PSAP by Schmid et al. (2006). Also, we note that Chow et al. (2009) reported higher and wavelength-dependent uncertainties between the filter-based and photoacoustic instruments (17$69 \%$, larger differences at higher wavelengths), but the difference in AAE measured with different instruments were below $25 \%$.

Since tar balls in the ambient atmosphere might have a size distribution different from those generated in our lab, the AAE of the atmospheric tar balls might also be somewhat different since AAE depends on the size distribution as well. The particle generation procedure used in the present study and the measurement of the optical properties were similar to those used by Hoffer et al. (2016). These authors calculated the AAE for tar balls using the ambient size distribution of these particles determined by Pósfai et al. (2004) and found that the AAE decreased from $\sim 2.9$ to $\sim 2.4$ in the range between 462 and $652 \mathrm{~nm}$. Since the size distribution of the generated particles in the present study was similar to 

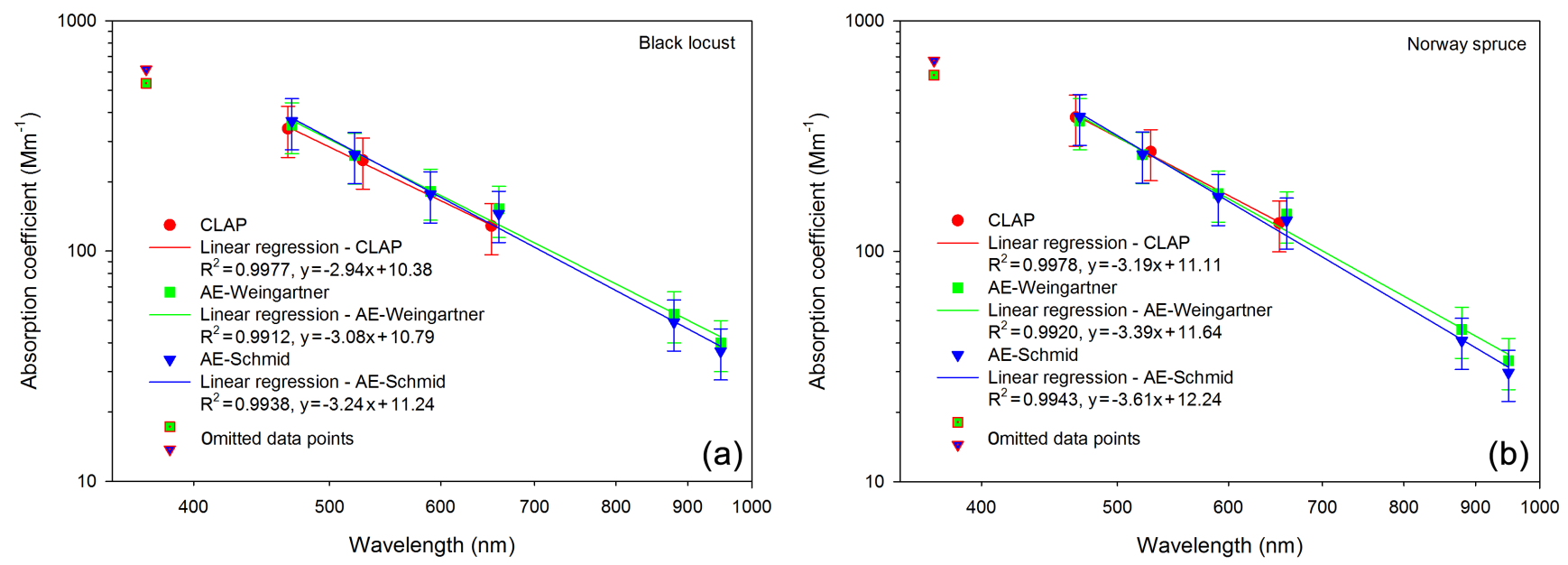

Figure 3. Absorption Ångström exponent of tar balls prepared from the liquid distillate of black locust and Norway spruce. The linear equations are calculated for the $\log A$ vs. $\log \lambda$ values (the data are also available in Table $\mathrm{S} 1$ in the Supplement.)

that obtained by Hoffer et al. (2016) and the AAEs of the tar balls in the same wavelength range $(462-652 \mathrm{~nm})$ were also similar, the AAE of freshly formed tar ball particles between 470 and $950 \mathrm{~nm}$ might be somewhat lower (by about $20 \%$ based on the results by Hoffer et al. (2016)) under ambient conditions than suggested by our calculations. On the other hand, Chow et al. (2009) showed that the AAE of ambient aerosol obtained from a photoacoustic analyzer (PA) is noticeably higher (by 14-23\%) than that obtained using filterbased instruments such as the aethalometer. In view of this, we propose that ambient freshly formed tar balls likely have an AAE of $2.7 \sim 3.6$ in the wavelength range from 470 to $950 \mathrm{~nm}$. (The value 2.7 is the lowest AAE value of the generated tar balls from oak reported by Hoffer et al. (2016), whereas the upper value of the given range is the highest AAE value obtained in the present study.)

As Fig. 3 demonstrates, the absorption of tar balls is nonnegligible in the near-IR range. The absorption coefficient at $880 \mathrm{~nm}$ is more than $10 \%$ of that measured at $470 \mathrm{~nm}$ for both wood types, undermining the common assumption that all $\mathrm{BrC}$ particles have zero or negligible absorption at $880 \mathrm{~nm}$. Even at $950 \mathrm{~nm}$, the absorption coefficient is about $10 \%$ of that at $470 \mathrm{~nm}$. The mass absorption efficiency of tar balls in the near-IR range is expected to be substantial as well, given that the mass absorption efficiency of tar balls was estimated to be in the range of $0.8-3 \mathrm{~m}^{2} \mathrm{~g}^{-1}$ at $550 \mathrm{~nm}$ by Hoffer et al. (2016). As Chow et al. (2009) demonstrated that absorption measured by filter-based instruments poses significant uncertainties, follow-up studies are desired to reduce the uncertainty of estimated tar ball absorption.

In spite of the uncertainties in the measurements of the absorption and other parameters, we estimated the index of refraction of the generated tar balls at different wavelengths (for the input optical parameters see Table S2 in the Supplement). In order to address the measurement uncertain- ties, nigrosin particles were generated and measured with the same setup used for tar ball measurements. The measured absorption and interpolated scattering coefficients at 652 and $633 \mathrm{~nm}$, respectively, were compared with those calculated using the size distribution and the well-established refraction index of nigrosin at a wavelength of $633 \mathrm{~nm}$ (Pinnick et al., 1973). The correction factors were calculated for nigrosin and then applied to the measured scattering and absorption coefficients of tar balls, which together with the size distribution served as input parameters for the inverse Mie calculations (Guyon et al., 2003). It was assumed that the same correction factors apply to nigrosin and tar balls, and also for the other wavelengths as well. For the calculations the absorption and scattering coefficient were extrapolated to the given wavelength if it was necessary. Table 1 summarizes the average refractive index of tar balls at different wavelengths. The obtained index of refraction data between 470 and $652 \mathrm{~nm}$ is very close to that obtained previously for turkey oak (Hoffer et al., 2016). The imaginary parts of the refractive index of tar balls produced from different wood types are very similar to each other at higher wavelength too. Here we note that - since tar balls form during burning and/or pyrolytic processes, in which the temperature might highly affect the composition and consequently the optical properties of the formed particles - the data in the table are not necessarily characteristic for every atmospheric tar ball particle. In our experiments we produced tar balls whose elemental composition and morphology match with those of atmospheric tar balls reported for the first time by Pósfai et al. (2004). The obtained index of refraction in the lower wavelength range (between $\sim 460$ and $\sim 650 \mathrm{~nm}$ ) is near the higher bound of the range found by Saleh et al. (2014) for ELVOCs and agrees well at $\sim 950 \mathrm{~nm}$. Since tar balls are produced and/or form in high-temperature processes (and also withstand the electron beam in the TEM), they are thermally 
Table 1. The average real (Re) and imaginary $(\mathrm{Im})$ part of the complex index of refraction of laboratory-generated tar balls from different wood types.

\begin{tabular}{|c|c|c|c|c|c|c|c|}
\hline \multirow[b]{2}{*}{ Absorption instrument } & \multirow[b]{2}{*}{ Wavelength (nm) } & \multicolumn{2}{|c|}{ Black locust } & \multicolumn{2}{|c|}{ Norway spruce } & \multicolumn{2}{|c|}{$\begin{array}{l}\text { Oak (Hoffer } \\
\text { et al., 2016) }\end{array}$} \\
\hline & & $\operatorname{Re}$ & $\operatorname{Im}$ & $\operatorname{Re}$ & $\operatorname{Im}$ & $\operatorname{Re}$ & Im \\
\hline CLAP & 467 & 1.86 & 0.34 & 1.88 & 0.33 & 1.84 & 0.27 \\
\hline CLAP & 550 & 1.86 & 0.25 & 1.88 & 0.24 & 1.84 & 0.21 \\
\hline CLAP & 652 & 1.77 & 0.18 & 1.82 & 0.16 & 1.82 & 0.15 \\
\hline CLAP & 880 & 1.64 & 0.10 & 1.84 & 0.09 & & \\
\hline CLAP & 950 & 1.61 & 0.09 & 1.85 & 0.08 & & \\
\hline Aethalometer & 880 & 1.64 & 0.09 & 1.83 & 0.08 & & \\
\hline Aethalometer & 950 & 1.60 & 0.07 & 1.83 & 0.07 & & \\
\hline
\end{tabular}

stable compounds and as such can be classified as extremely low volatility compounds. On the other hand the obtained index of refraction is somewhat lower (especially at longer wavelengths) than those reported by Alexander et al. (2008).

\subsection{Estimated contribution of tar balls to the absorption at K-puszta station}

The objective of this section is to assess the possible contribution of tar ball particles to the absorption at a given station (where the size distribution and the number share of tar balls were measured previously by TEM analyses; Pósfai et al., 2004), based on our finding that absorption of these particles in the near-IR range is non-negligible. During winter the $\mathrm{K}$-puszta station is affected by biomass smoke from domestic heating. Pósfai et al. (2004) investigated aerosol samples collected at this station and identified tar ball particles by electron microscopy. The concentration of levoglucosan is also elevated at the station during winter (Puxbaum et al., 2007).

In order to estimate the contribution of tar balls to the absorption measured at the K-puszta station, we calculated the absorption coefficient of a tar ball population with a Mie code at $652 \mathrm{~nm}$ and compared the calculated value with the measured absorption coefficient at this wavelength. The index of refraction of tar balls at $652 \mathrm{~nm}(1.82-0.15 i)$ was taken from Hoffer et al. (2016). For the comparison we used the measured absorption coefficient (CLAP, at $652 \mathrm{~nm}$ ) as well as the measured particle number concentration (DMPS, between 7 and $800 \mathrm{~nm}$ ) in K-puszta during 10 days between 7 and 27 January 2014. The shape of the size distribution of tar balls was taken from Pósfai et al. (2004) as it was determined from tar balls collected in K-puszta. Furthermore we assumed that the number share of tar ball particles is $20 \%$, as Pósfai et al. (2004) reported that the contribution of tar ball particles to the total number concentration varies between 0 and $40 \%$ in K-puszta. If we consider that only tar balls and soot are the absorbing components at $652 \mathrm{~nm}$, the contribution of the tar balls to the absorption is $17-38 \%$, on average $29 \%$. Even if we consider that only $5 \%$ of the particles are tar balls, the contribution to the absorption is still 4-9\% (on average $7 \%$ ) at $652 \mathrm{~nm}$. This also indicates that the contribution of the tar balls to the absorption at higher wavelengths might be significant too, since the AAE of tar balls is 2.7-3.6, which means that the absorption does not decrease steeply towards the IR range of the spectrum. (Based on the comparison of the extrapolated measurement data with the estimated absorption coefficient for tar balls obtained for $880 \mathrm{~nm}$, the contribution of tar balls to the absorption at $880 \mathrm{~nm}$ is $5-19 \%$ at the K-puszta station.)

Here we note that the AAE measured at the station (1.581.88 , on average 1.71 , between 467 and $652 \mathrm{~nm}$ ) during the investigated period (10 days, between 7 and 27 January 2014) is very close to that $(\mathrm{AAE}=1.76$ between 467 and $652 \mathrm{~nm})$ obtained by the estimation assuming soot $(\mathrm{AAE}=1)$ and tar ball (AAE $=3.15)$ as the only absorbing components, the latter causing on average $29 \%$ of the absorption at $652 \mathrm{~nm}$. Since the contribution of humic-like substances to the absorption (few per cent at $550 \mathrm{~nm}$; Hoffer et al., 2006) is incorporated in the measured AAE, the estimated contribution of the tar ball particles might be considered as an upper limit. If we assume that the contribution of tar ball particles to the total particle number concentration is only $5 \%$ (which also means that the contribution of tar balls to the absorption at $652 \mathrm{~nm}$ is $7 \%$; see above), the calculated AAE, assuming soot and tar ball as the only absorbing components, decreases significantly; it is on average 1.19 between 467 and $652 \mathrm{~nm}$. Since the measured AAE is higher than the calculated value, the contribution of $7 \%$ to the absorption (5\% in number concentration) can be considered as a lower value during the investigated period.

\section{Summary}

We have used a CLAP to measure the absorption of tar ball particles between 462 and $652 \mathrm{~nm}$ and an aethalometer between 470 and $950 \mathrm{~nm}$. The aethalometer has two measurement channels in the near-infrared region, 880 and $950 \mathrm{~nm}$, thus allowing for direct measurement of the light absorption in the red-infrared part of the spectrum. The AAE of tar balls 
over $470 \sim 950 \mathrm{~nm}$ is in the range between 2.7 and 3.6, but more importantly the absorption coefficient at $880 \mathrm{~nm}$ exceeds $10 \%$ of that at $470 \mathrm{~nm}$ for both wood types (Fig. 3), clearly disproving the common assumption that all $\mathrm{BrC}$ particles have zero or negligible absorption at $880 \mathrm{~nm}$.

The determination of the contribution of $\mathrm{BrC}$ to aerosol absorption (Bahadur et al., 2012; Kirchstetter and Thatcher, 2012; Lu et al., 2015) has been based on the explicit assumption that $\mathrm{BrC}$ has zero absorption at a wavelength of $700 \mathrm{~nm}$ or larger. The findings of the present study strongly challenge this common assumption. One of the resulting implications may be that the role of $\mathrm{BC}$ - a significant fraction of which is derived from fossil fuel combustion (diesel soot) is likely overestimated in global radiative forcing estimates if the aerosol absorption in the red and near-infrared spectrum is attributed exclusively to BC. Our results support the finding by Alexander et al. (2008) that spherical brown carbon particles effectively absorb near-infrared radiation as well as the finding by Jacobson et al. (2014) that they also have an important role in global warming.

Data availability. Experimental data presented here are available in the Supplement and upon request to the authors (hoffera@almos.uni-pannon.hu).

\section{The Supplement related to this article is available online at https://doi.org/10.5194/amt-10-2353-2017-supplement.}

Competing interests. The authors declare that they have no conflict of interest.

Acknowledgements. The authors thank NOAA ESRL laboratory and the University of Helsinki for their support in data management and the size distribution measurements. This project has received funding from the European Union's Horizon 2020 research and innovation programme under grant agreement no. 654109 . This study was also funded by the National Science Foundation (AGS-1455759).

Edited by: Alexander Kokhanovsky

Reviewed by: three anonymous referees

\section{References}

Adachi, K. and Buseck, P. R.: Atmospheric tar balls from biomass burning in Mexico, J. Geophys. Res.-Atmos., 116, D05204, https://doi.org/10.1029/2010jd015102, 2011.

Alexander, D. T. L., Crozier, P. A., and Anderson, J. R.: Brown carbon spheres in East Asian outflow and their optical properties, Science, 321, 833-836, https://doi.org/10.1126/science.1155296, 2008.
Anderson, T. L. and Ogren, J. A.: Determining aerosol radiative properties using the TSI 3563 integrating nephelometer, Aerosol Sci. Tech., 29, 57-69, 1998.

Andreae, M. O. and Gelencsér, A.: Black carbon or brown carbon? The nature of light-absorbing carbonaceous aerosols, Atmos. Chem. Phys., 6, 3131-3148, https://doi.org/10.5194/acp-63131-2006, 2006.

Bahadur, R., Praveen, P. S., Xu, Y., and Ramanathan, V.: Solar absorption by elemental and brown carbon determined from spectral observations, P. Natl. Acad. Sci. USA, 109, 17366-17371, https://doi.org/10.1073/pnas.1205910109, 2012.

Bond, T. C., Anderson, T. L., and Campbell, D.: Calibration and intercomparison of filter-based measurements of visible light absorption by aerosols, Aerosol Sci. Tech., 30, 582-600, https://doi.org/10.1080/027868299304435, 1999.

Chakrabarty, R. K., Moosmüller, H., Chen, L.-W. A., Lewis, K., Arnott, W. P., Mazzoleni, C., Dubey, M. K., Wold, C. E., Hao, W. M., and Kreidenweis, S. M.: Brown carbon in tar balls from smoldering biomass combustion, Atmos. Chem. Phys., 10, 63636370, https://doi.org/10.5194/acp-10-6363-2010, 2010.

Chakrabarty, R. K., Gyawali, M., Yatavelli, R. L. N., Pandey, A., Watts, A. C., Knue, J., Chen, L.-W. A., Pattison, R. R., Tsibart, A., Samburova, V., and Moosmüller, H.: Brown carbon aerosols from burning of boreal peatlands: microphysical properties, emission factors, and implications for direct radiative forcing, Atmos. Chem. Phys., 16, 3033-3040, https://doi.org/10.5194/acp-16-3033-2016, 2016.

Chow, J. C., Watson, J. G., Doraiswamy, P., Chen, L.-W. A., Sodeman, D. A., Lowenthal, D. H., Park, K., Arnott, W. P., and Motallebi, N.: Aerosol light absorption, black carbon, and elemental carbon at the Fresno Supersite, California, Atmos. Res., 93, 874887, 10.1016/j.atmosres.2009.04.010, 2009.

Collaud Coen, M., Weingartner, E., Apituley, A., Ceburnis, D., Fierz-Schmidhauser, R., Flentje, H., Henzing, J. S., Jennings, S. G., Moerman, M., Petzold, A., Schmid, O., and Baltensperger, U.: Minimizing light absorption measurement artifacts of the Aethalometer: evaluation of five correction algorithms, Atmos. Meas. Tech., 3, 457-474, https://doi.org/10.5194/amt-3-4572010, 2010.

Drinovec, L., Gregoric, A., Zotter, P., Wolf, R., Bruns, E. A., Prévôt, A. S. H., Petit, J.-E., Favez, O., Sciare, J., Arnold, I. J., Chakrabarty, R. K., Moosmüller, H., Filep, A., and Mocnik, G.: The filter-loading effect by ambient aerosols in filter absorption photometers depends on the coating of the sampled particles, Atmos. Meas. Tech., 10, 1043-1059, https://doi.org/10.5194/amt10-1043-2017, 2017.

Guyon, P., Boucher, O., Graham, B., Beck, J., Mayol-Bracero, O. L., Roberts, G. C., Maenhaut, W., Artaxo, P., and Andreae, M. O.: Refractive index of aerosol particles over the Amazon tropical forest during LBA-EUSTACH 1999, J. Aerosol. Sci., 34, 883907, https://doi.org/10.1016/S0021-8502(03)00052-1, 2003.

Hoffer, A., Gelencsér, A., Guyon, P., Kiss, G., Schmid, O., Frank, G. P., Artaxo, P., and Andreae, M. O.: Optical properties of humiclike substances (HULIS) in biomass-burning aerosols, Atmos. Chem. Phys., 6, 3563-3570, https://doi.org/10.5194/acp-6-35632006, 2006.

Hoffer, A., Tóth, A., Nyiro-Kósa, I., Pósfai, M., and Gelencsér, A.: Light absorption properties of laboratory-generated 
tar ball particles, Atmos. Chem. Phys., 16, 239-246, https://doi.org/10.5194/acp-16-239-2016, 2016.

Jacobson, M. Z.: Effects of biomass burning on climate, accounting for heat and moisture fluxes, black and brown carbon, and cloud absorption effects, J. Geophys. Res.-Atmos., 119, 89809002, https://doi.org/10.1002/2014jd021861, 2014.

Kirchstetter, T. W. and Thatcher, T. L.: Contribution of organic carbon to wood smoke particulate matter absorption of solar radiation, Atmos. Chem. Phys., 12, 6067-6072, https://doi.org/10.5194/acp-12-6067-2012, 2012.

Laskin, A., Laskin, J., and Nizkorodov, S. A.: Chemistry of Atmospheric Brown Carbon, Chem. Rev., 115, 4335-4382, https://doi.org/10.1021/cr5006167, 2015.

Limbeck, A., Kulmala, M., and Puxbaum, H.: Secondary organic aerosol formation in the atmosphere via heterogeneous reaction of gaseous isoprene on acidic particles, Geophys. Res. Lett., 30, 1996, https://doi.org/10.1029/2003gl017738, 2003.

Lu, Z., Streets, D. G., Winijkul, E., Yan, F., Chen, Y., Bond, T. C., Feng, Y., Dubey, M. K., Liu, S., Pinto, J. P., and Carmichael, G. R.: Light Absorption Properties and Radiative Effects of Primary Organic Aerosol Emissions, Environ. Sci. Technol., 49, 48684877, https://doi.org/10.1021/acs.est.5b00211, 2015.

Lukács, H., Gelencsér, A., Hammer, S., Puxbaum, H., Pio, C., Legrand, M., Kasper-Giebl, A., Handler, M., Limbeck, A., Simpson, D., and Preunkert, S.: Seasonal trends and possible sources of brown carbon based on 2-year aerosol measurements at six sites in Europe, J. Geophys. Res.-Atmos., 112, D23S18, https://doi.org/10.1029/2006jd008151, 2007.

Myhre, G., Samset, B. H., Schulz, M., Balkanski, Y., Bauer, S., Berntsen, T. K., Bian, H., Bellouin, N., Chin, M., Diehl, T., Easter, R. C., Feichter, J., Ghan, S. J., Hauglustaine, D., Iversen, T., Kinne, S., Kirkevåg, A., Lamarque, J.-F., Lin, G., Liu, X., Lund, M. T., Luo, G., Ma, X., van Noije, T., Penner, J. E., Rasch, P. J., Ruiz, A., Seland, Ø., Skeie, R. B., Stier, P., Takemura, T., Tsigaridis, K., Wang, P., Wang, Z., Xu, L., Yu, H., Yu, F., Yoon, J.-H., Zhang, K., Zhang, H., and Zhou, C.: Radiative forcing of the direct aerosol effect from AeroCom Phase II simulations, Atmos. Chem. Phys., 13, 1853-1877, https://doi.org/10.5194/acp13-1853-2013, 2013.

Ogren, J. A.: Comment on Calibration and Intercomparison of Filter-Based Measurements of Visible Light Absorption by Aerosols, Aerosol Sci. Tech., 44, 589-591, https://doi.org/10.1080/02786826.2010.482111, 2010.
Petzold, A., Ogren, J. A., Fiebig, M., Laj, P., Li, S.-M., Baltensperger, U., Holzer-Popp, T., Kinne, S., Pappalardo, G., Sugimoto, N., Wehrli, C., Wiedensohler, A., and Zhang, X.-Y.: Recommendations for reporting "black carbon" measurements, Atmos. Chem. Phys., 13, 8365-8379, https://doi.org/10.5194/acp13-8365-2013, 2013.

Pinnick, R. G., Rosen, J. M., and Hofmann, D. J.: Measured lightscattering properties of individual aerosol particles compared to Mie scattering theory, Appl. Optics, 12, 37-43, 1973.

Pósfai, M., Gelencsér, A., Simonics, R., Arató, K., Li, J., Hobbs, P. V., and Buseck, P. R.: Atmospheric tar balls: Particles from biomass and biofuel burning, J. Geophys. Res.-Atmos., 109, D06213, https://doi.org/10.1029/2003jd004169, 2004.

Puxbaum, H., Caseiro, A., Sanchez-Ochoa, A., Kasper-Giebl, A., Claeys, M., Gelencsér, A., Legrand, M., Preunkert, S., and Pio, C.: Levoglucosan levels at background sites in Europe for assessing the impact of biomass combustion on the European aerosol background, J. Geophys. Res.-Atmos., 112, https://doi.org/10.1029/2006jd008114, 2007.

Saleh, R., Robinson, E. S., Tkacik, D. S., Ahern, A. T., Liu, S., Aiken, A. C., Sullivan, R. C., Presto, A. A., Dubey, M. K., Yokelson, R. J., Donahue, N. M., and Robinson, A. L.: Brownness of organics in aerosols from biomass burning linked to their black carbon content, Nat. Geosci., 7, 647-650, 2014.

Schmid, O., Artaxo, P., Arnott, W. P., Chand, D., Gatti, L. V., Frank, G. P., Hoffer, A., Schnaiter, M., and Andreae, M. O.: Spectral light absorption by ambient aerosols influenced by biomass burning in the Amazon Basin. I: Comparison and field calibration of absorption measurement techniques, Atmos. Chem. Phys., 6, 3443-3462, https://doi.org/10.5194/acp-6-3443-2006, 2006.

Tóth, A., Hoffer, A., Nyiro-Kósa, I., Pósfai, M., and Gelencsér, A.: Atmospheric tar balls: aged primary droplets from biomass burning?, Atmos. Chem. Phys., 14, 6669-6675, https://doi.org/10.5194/acp-14-6669-2014, 2014.

Weingartner, E., Saathoff, H., Schnaiter, M., Streit, N., Bitnar, B., and Baltensperger, U.: Absorption of light by soot particles: determination of the absorption coefficient by means of aethalometers, J. Aerosol Sci., 34, 1445-1463, https://doi.org/10.1016/s0021-8502(03)00359-8, 2003. 